\title{
Understanding the Process of Latent Infection of Canker-Causing Pathogens in Stone Fruit and Nut Crops in California
}

\author{
Yong Luo, ${ }^{1, \dagger}$ Paulo S. F. Lichtemberg, ${ }^{1}$ Franz J. A. Niederholzer, ${ }^{2}$ Danielle M. Lightle, ${ }^{3}$ Daniel G. Felts, ${ }^{1}$ and \\ Themis J. Michailides ${ }^{1, \dagger}$ \\ ${ }^{1}$ Department of Plant Pathology, University of California-Davis, Kearney Agricultural Research and Extension Center, Parlier, \\ CA 93648 \\ ${ }^{2}$ University of California - Cooperative Extension, Colusa/Sutter/Yuba Counties, Yuba City, CA 95991 \\ ${ }^{3}$ University of California - Cooperative Extension, Butte/Glenn/Tehama Counties, Orland, CA 95963
}

\begin{abstract}
The Botryosphaeriaceae family is considered a fungal family that includes pathogens causing latent infection of woody plants, and a number of species were identified as causal pathogens of canker and shoot blight diseases. To better understand the process of latent infection of major canker-causing pathogens in woody tissues in different tree crops important in California, shoot and bud samples were randomly collected from four tree crops: almond, dried plum, pistachio, and walnut. The previously developed DNA primers and quantitative real-time PCR (qPCR) assay systems were applied to detect six canker-causing pathogen groups, including Botryosphaeria dothidea, and species of Cytospora, Diplodia, Lasiodiplodia, Neofusicoccum, and Phomopsis. The concepts of molecular severity (MS) and latent infection index (LII) were introduced and applied to quantify the latent infection levels for these samples. Variation in incidence of latent infection among pathogen groups

observed in two dried plum (prune) orchards. Most orchards showed high incidences of $B$. dothidea and Lasiodiplodia spp. and moderate incidences of Neofusicoccum spp. Variations in MS were observed among samples of the studied orchards, ranging from 4 to 8 . The overall results of LII demonstrated that species of Diplodia and Phomopsis were less important in population development of canker-causing pathogens at the latent phase. Lasiodiplodia spp. were the most aggressive and had been well developed in populations among the studied tree crops. Cytospora spp. became predominant in two of the three dried plum orchards, whereas B. dothidea and Neofusicoccum spp. showed trends of increase in incidence across various tree crops. This study also demonstrated the usefulness of this sensitive qPCR approach in providing evidence of the latent phase of major canker-causing pathogens of stone fruit and nut crops at an early stage of latent infection in woody plant tissues.
\end{abstract} was observed, whereas the incidences were relatively low among species of Phomopsis and Diplodia. High incidences of Cytospora spp. were
Keywords: etiology, pathogen detection, epidemiology, qPCR
Stone fruits (apricot, cherry, nectarine, peach, plum, and dried plum) and nut crops (almond, pistachio, and walnut) are over $\$ 1.2$ billion and over $\$ 8.2$ billion industries in California, respectively. Based on the 2017 statistics, California accounted for $46 \%$ of the United States fruit and nut production. However, Botryosphaeria canker and shoot blight diseases, caused by various fungal species of Botryosphaeriaceae, are becoming more and more severe, thereby impacting on the production of stone fruits and nut crops in California (Chen et al. 2014a, 2014b; Michailides 1991; Michailides and Morgan 2010). These diseases kill branches, blight leaves and fruit, and also result in cankers on branches, shoots, and fruiting spurs. Initially, the fungal pathogen Botryosphaeria dothidea was identified as the major causal agent of panicle and shoot blight of pistachio and band canker of almond in California (English et al. 1975; Michailides 1991).

The latency phase of Botryosphaeriaceae had been reviewed extensively by Slippers and Wingfield (2007). Although the initial process of infection in some tree crops is still unclear, the cytological and histological observations showed strong evidence of existence and development of the pathogen inside plant tissues (Slippers and

${ }^{\dagger}$ Corresponding authors: Y. Luo; ygluo@ucanr.edu and T. J. Michailides; tjmichailides@ucanr.edu

Funding: This research was supported by the California Dried Plum Research Board (Roseville, CA), the California Pistachio Research Board (Fresno, CA), the Almond Board of California (Modesto, CA), and the California Walnut Board (Folsom, CA).

The author(s) declare no conflict of interest.

Accepted for publication 8 April 2019.

() 2019 The American Phytopathological Society
Wingfield 2007). The factors triggering the latent infections to grow and cause a canker disease are unknown but need further investigation. It is thought that the disease development through expression of visible symptoms follows an abiotic stress or biological stress of tree growth rather than infection itself (Slippers and Wingfield 2007). Such stress may include heat, drought, wound, frost, hail damage, nutrition deficiency, and others. Climatic changes such as extreme heat, cold, drought, and flood conditions lasting long might be important factors that trigger canker development and expression widely and in many crops in California (Pathak et al. 2018).

Subsequent studies on the taxonomy of Botryosphaeriaceae isolated from nut crops in California showed that eight to 10 different species in this family were associated with these canker and blight diseases (Chen et al. 2014a, 2014b; Inderbitzin et al. 2010). Specifically, for the Botryosphaeria panicle and shoot blight of pistachio, studies focused on disease epidemiology (Ahimera et al. 2004; Mila et al. 2005; Ntahimpera et al. 2002), inoculum sources and spread (Ma et al. 2004; Michailides and Morgan 1993a, 1993b), population structure (Ma et al. 2001a, 2004), fungicide resistance (Ma et al. 2001b), and disease management (Michailides and Morgan 2010; Mila and Michailides 2006). Recently, Botryosphaeriaceae and Diaporthaceae were defined as two families containing a number of genera (Phillips et al. 2013) with important canker-causing species in pistachio (Chen et al. 2014b), English walnut (Chen et al. 2014a), almond (English et al. 1975; Inderbitzin et al. 2010), grapevine (Úrbez-Torres and Gubler 2009; Úrbez-Torres et al. 2006), olive (Moral et al. 2010; Úrbez-Torres et al. 2013), citrus (Adesemoye et al. 2014), avocado (McDonald and Eskalen 2011), and other agricultural, forest (Aćimović et al. 2018), and ornamental trees and bushes in California and in other regions worldwide (Damm et al. 2007).

The Botryosphaeriaceae family was studied extensively (Phillips et al. 2013), and most of its members include species with a 
world-wide distribution. Among them, 17 genera and 110 species were identified and classified based on morphological and molecular characteristics. The molecular characteristics include phylogenetic relationships among genera through multilocus tree cluster analysis. Among these genera, Botryosphaeria, Diplodia, Dothiorella, Lasiodiplodia, Neofusicoccum, and Neoscytalidium are the most common ones containing some species of canker-causing pathogens of fruit and nut trees in California (Chen et al. 2014a, 2014b). Additionally, nine families of ascomycete order Diaporthales had been studied (Rossman et al. 2007), and the information on this order has been updated by the new studies on families of Diaporthales by Senanayake et al. (2017). The genus Phomopsis (teleomorph Diaporthe) includes several important plant pathogens associated with tree hosts and also consists of a number of latent and saprobic species (Diogo et al. 2010; Gomes et al. 2013; Udayanga et al. 2011). The canker-causing pathogens Cytospora spp. belong to the ascomycetes in the order Diaporthales (Senanayake et al. 2017) and the family Valsaceae, comprising about 500 species in this genus and causing various plant diseases (Adams and Jacobi 2016). Thus far, the two species at the anamorphic stage, Cytospora cincta (Leucocytospora cincta) and C. leucostoma (Leucostoma persoonii) were found to be common pathogens of fruit trees.

Some species of Botryosphaeriaceae were defined as canker-causing pathogens because they can infect directly through lenticels, stomata, or other openings on healthy plants (Brown and Hendrix 1981; Kim et al. 1999; Michailides 1991). However, the canker disease epidemics are relatively complex. Usually more than one species is involved in these canker disease complexes. These pathogens frequently form pycnidia under the epidermal layers of branches and/or other woody tissues, which produce the asexual, water-splashed conidia (pycnidiospores). The conidia can cause latent infections that can survive in plant tissues for long before canker symptoms appear. The canker symptoms also vary greatly from typical lesions to death of entire branches, scaffolds, or even trunks of the trees, with the last leading to tree death. The pathogens can also infect fruit leading to blighted fruit, thus significantly affecting yields and fruit quality.

How the latent pathogens develop in the plant tissue over long period of time and how this development relates to canker expression pose critical questions to understand the disease epidemic mechanisms. Identification and quantification of such latent pathogens in plant tissue are necessary to help define and describe their whole development process. We need to understand the current latent situations in different tree crops in California before the expression of symptoms, so that large-area disease management strategies can be designed. We also need an efficient method to track the development of latent fungal species to determine how they could induce disease expression. Understanding the population dynamics of the latent pathogens in the plant tissue becomes a core issue to estimate possible risk of canker disease epidemics.
Furthermore, evaluation of disease management also needs information on the changes in latent pathogen populations related to various control methods.

Obviously, the traditional plating method to isolate the pathogens in their latent infection phase is not sensitive enough to efficiently and accurately provide needed information at an early stage of disease after infection by the pathogen. The plating method also cannot quantify latent infection level in plant tissues. In this study, we collected shoot and bud samples from different tree crops in California. We used previously designed pathogen group-specific primers and applied a previously published quantitative real-time PCR (qPCR) method (Luo et al. 2017) to quantify infection levels of different pathogen groups for these samples. Using the obtained data, we established the methodology to define the infection levels and population situation of six canker-causing pathogen groups, such as B. dothidea and species of Cytospora, Diplodia, Lasiodiplodia, Neofusicoccum, and Phomopsis. The objectives of this study were to (i) understand the current situation of the studied latent fungal pathogen groups in stone fruits and nut crops in California, (ii) determine the population levels of the studied pathogen groups in the latent phase, and (iii) compare infection and population levels of different pathogen groups among different tree crops.

\section{Materials and Methods}

Sample collection. This study focused on samples obtained from one almond, three pistachio, three dried plum (prune), and two walnut orchards in California (Table 1). In each orchard, samples of asymptomatic shoots, 1 to 3 years old, were collected at different periods of time from 2015 to 2017 . The sample sizes were from 14 to 34 shoots per orchard, depending on sampling availability (Table 1). The Dried plum-1 orchard showed severe canker disease history with typical canker symptoms, whereas the others showed much less disease severity, with most symptomless shoots. Shoot dieback was not observed in these orchards. Bud samples, from 10 to 34 buds per orchard (Table 1), were also collected from an almond orchard and from one each of the pistachio and walnut orchards. These orchards were of different age and used different irrigation systems (Table 1). Different numbers of samples were collected depending on the specific situation of the sampled orchards. The samples were collected during the winter and spring in different years (Table 1).

Shoots in each sample were cut into a 3 -cm-long piece, washed under running tap water to remove the surface dust, soaked in $0.525 \%$ $\mathrm{NaOCl}$ (10\% commercial bleach) for 15 min for surface sterilization, washed with sterile distilled water three times, and placed on paper towels to dry in ambient air for about $24 \mathrm{~h}$. The shoot sections were ground into fine pieces with a manual pencil sharpener (X-Acto KS Manual Pencil Sharpener, Elmer's Products, High Point, NC), weighed (about $0.2 \mathrm{~g}$ for each sample), and extracted to obtain DNA using the FastDNA Spin kit (MP Biomedicals, Santa Ana, CA) by following the manufacturer's instructions. The final DNA

Table 1. Orchards of different tree crops used for shoot and bud samplings in this study

\begin{tabular}{|c|c|c|c|c|c|c|c|c|}
\hline Crop & Location & $\begin{array}{c}\text { Orchard age } \\
\text { (years) }\end{array}$ & Orchard code & $\begin{array}{l}\text { Plant } \\
\text { tissue }\end{array}$ & $\begin{array}{c}\text { Collection } \\
\text { date }\end{array}$ & $\begin{array}{c}\text { No. of } \\
\text { samples }\end{array}$ & $\begin{array}{c}\text { Shoot age } \\
\text { (years) }\end{array}$ & $\begin{array}{l}\text { Irrigation } \\
\text { type }\end{array}$ \\
\hline Almond & KARE & 12 & Almond-1 & Shoot & $2 / 11 / 2016$ & 34 & $1-2$ & Flood \\
\hline Almond & KARE & 12 & Almond-1 & Bud & 2/11/2016 & 34 & NA & Flood \\
\hline Dried plum & Yuba, CA & 21 & Dried plum-1 & Shoot & $12 / 6 / 2015$ & 17 & $1-2$ & Drip \\
\hline Dried plum & Yuba, CA & 21 & Dried plum-2 & Shoot & $12 / 9 / 2015$ & 14 & $1-2$ & Flood \\
\hline Dried plum & KARE & 24 & Dried plum-3 & Shoot & $2 / 28 / 2017$ & 32 & $1-3$ & Flood \\
\hline Pistachio & KARE & 27 & Pistachio-1 & Shoot & $3 / 19 / 2016$ & 32 & $1-3$ & Flood \\
\hline Pistachio & KARE & 27 & Pistachio-2 & Shoot & $1 / 20 / 2016$ & 32 & $1-3$ & Drip \\
\hline Pistachio & KARE & 27 & Pistachio-2 & Bud & $1 / 20 / 2016$ & 32 & NA & Drip \\
\hline Pistachio & Butte, CA & 35 & Pistachio-3 & Shoot & $3 / 18 / 2016$ & 32 & $1-2$ & Flood \\
\hline Walnut & Butte, Nicolaus, CA & $>20$ & Walnut-1 & Shoot & $2 / 18 / 2016$ & 32 & 1 & Flood \\
\hline Walnut & KARE & 11 & Walnut-2 & shoot & $1 / 5 / 2016$ & 26 & $1-2$ & Flood \\
\hline Walnut & KARE & 11 & Walnut-2 & Bud & $1 / 5 / 2016$ & 10 & NA & Flood \\
\hline
\end{tabular}

${ }^{\mathrm{z}}$ Different number of shoots and bud samples per orchard were collected. The quantitative real-time PCR assay was applied to process these samples to quantify the latent infection levels. KARE $=$ Kearney Agricultural Research and Extension Center, and NA = not applicable. 
was dissolved in $60 \mu \mathrm{l}$ of nuclease-free water for each sample and stored at $-20^{\circ} \mathrm{C}$ for later use.

qPCR assay. The six previously published primer pairs (Luo et al. 2017) specific to the corresponding six canker-causing pathogen groups were used in this study (Table 2). The qPCR amplifications were performed with a CFX96 Touch Real-Time PCR Detection System (Bio-Rad Laboratories, Hercules, CA) using SYBR Green I fluorescent dye. Amplifications were conducted in 25- $\mu$ l aliquots containing $12.5 \mu \mathrm{l}$ of SYBR Green Supermix (Biotool, Houston, TX), $2 \mu$ l of template DNA extracted or $2 \mu l$ of nuclease-free water as a negative control, $0.25 \mu \mathrm{l}$ of each forward and reverse primers (10 $\mu \mathrm{M}$ each), and $10 \mu \mathrm{l}$ of nuclease-free water. The following parameters were used for $\mathrm{qPCR}$ amplifications: an initial preheat for $3 \mathrm{~min}$ at $95^{\circ} \mathrm{C}$, followed by 40 cycles at $94^{\circ} \mathrm{C}$ for $15 \mathrm{~s}, 58^{\circ} \mathrm{C}$ for $30 \mathrm{~s}, 72^{\circ} \mathrm{C}$ for $30 \mathrm{~s}$, and then $73^{\circ} \mathrm{C}$ for $1 \mathrm{~s}$ in order to detect and quantify the fluorescence at a temperature above the denaturation of primer-dimers. After the amplifications were completed, melting curves were obtained based on a standard protocol from the manufacturer's instructions and were used to confirm the signal from the target product without primer-dimers. Thus, the temperature at which the peak of melting curve was located was checked to confirm the correct PCR product. The DNA extracted from pure culture of each studied pathogen species was used as the positive control and water as the negative control in each reaction (Table 2). Thus, the cycle threshold $(\mathrm{Ct})$ value was obtained for each primer pair for each sample. The standard curve for each of the six pathogen groups established in a previous study (Luo et al. 2017) was applied to calculate the corresponding DNA concentration of each sample based on the $\mathrm{Ct}$ value obtained from each reaction.

Quantification of latent infection level. The level of latent infection for each sample was quantified as the molecular severity (MS) described in a previous study (Luo et al. 2017). Briefly, MS = $\log _{10}(P / H)$, where $P$ is the weight of the pathogen's DNA in femtograms (fg), which is calculated by using the equation of the standard curve for the corresponding pathogen based on the $\mathrm{Ct}$ value from its reaction with the corresponding primers (Table 2), and where $H$ is the shoot/bud weight in grams. Thus, the range of MS value is 0 to 15 . However, because when no infection is detected we assign MS = 0 , the theoretically detectable amount of pathogen DNA in $1 \mathrm{~g}$ of shoot should be $>1 \mathrm{fg}$ (Luo et al. 2017). Therefore, for each sample, six reactions were conducted using the corresponding primer pairs to obtain six MS values each for each of the six corresponding pathogens (Table 2).

Data analysis. For the samples (shoots or buds) of each orchard, mean MS value from samples showing a positive result and the corresponding standard deviation (SD) were calculated for each of the six pathogen groups. For the samples from each orchard, the percentage of plant tissues (shoots or buds) showing a positive result from qPCR was calculated as the incidence of latent infection (\%) for each of the six pathogen groups. To describe the overall situation of latent infection, we introduced the concept of latent infection index (LII): $\mathrm{LII}=$ incidence $\times \mathrm{MS} / 15$, which was in a range from 0 to $100 \%$. LII combined information of incidence and severity for an orchard; thus, it was used to present and compare the situation of latent infection levels among orchards. The concept of statistical analysis on multiple comparisons in proportion data (Zar 1999), as well as a corresponding SAS program (https://support.sas.com/ resources/papers/proceedings/proceedings/sugi31/204-31.pdf)

with a certain modification, were used to determine the differences in incidence and LII among the studied orchards of various tree crops for each pathogen group. Comparison of values of mean MS among orchards of the various tree crops was performed with the ANOVA procedure of SAS (version 9.4, SAS Institute, Cary, NC). To determine the importance of the studied pathogen groups in causing latent infections in each tree crop, the data from different orchards of the same tree crop were combined. The same data analysis approaches described above were performed to determine the significance in incidence, mean MS, and LII among pathogen groups for each tree crop on shoots and buds. We also arbitrarily defined four levels of pathogen population establishment situation for each pathogen group according to the incidence level as follows: I, the pathogen is not found when incidence $=0$; II, establishment of the pathogen latent population is in a starting mode when $0<$ incidence $\leq 25 \%$; III, establishment of the pathogen latent population is in a development mode when $25<$ incidence $\leq 75 \%$; and IV, the pathogen latent population is well established when incidence $>75 \%$. Using the above concepts, the latent infection level for each pathogen group was described for each sampled orchard.

\section{Results}

Incidence of latent infection in shoots. Although all six pathogen groups were observed in some tree crops, the incidences of latent infection of Phomopsis spp. and Diplodia spp. were comparatively lower than those of the other four pathogen groups for all the studied tree crops (Fig. 1). The orchard Dried plum-3 showed significant lower incidences of Cytospora spp., Diplodia spp., Neofusicoccum spp., and Phomopsis spp. (Fig. 1) than other orchards. For Almond-1 orchard, the incidences of latent infection of B. dothidea, Cytospora, and species of Lasiodiplodia and Neofusicoccum were all greater than 50\%, whereas those of species of Phomopsis and Diplodia were only 18 and $10 \%$, respectively. B. dothidea was present in all orchards, whereas the two dried plum orchards and one walnut orchard showed higher incidences compared with those of the three pistachio orchards (Fig. 1). The incidences of Cytospora spp. were $100 \%$ in two dried plum orchards (Dried plum-1 and Dried plum2), significantly higher than other orchards, implying that this pathogen was more predominant in dried plums than in other tree crops. All orchards showed high incidence $(>60 \%)$ of Lasiodiplodia spp.

Table 2. Primer sequences for six canker-causing pathogen groups and their corresponding standard curve equations used to quantify the latent infection level of shoots and buds of different tree crops by using a quantitative real-time PCR (qPCR) assay (Luo et al. 2017) in this study

\begin{tabular}{|c|c|c|c|c|c|}
\hline $\begin{array}{l}\text { Pathogen } \\
\text { group }\end{array}$ & Primer name & Primer sequence $\left(5^{\prime}\right.$ - $\left.3^{\prime}\right)$ (forward/reverse) & $\begin{array}{l}\text { Product } \\
\text { size (bp) }\end{array}$ & Standard curve ${ }^{y}$ & Representative species $^{z}$ \\
\hline $\begin{array}{l}\text { Botryosphaeria } \\
\text { dothidea }\end{array}$ & $\mathrm{BdF} / \mathrm{BdR}$ & $\begin{array}{l}\text { CAGCGTGGGAGAACATCAA/ } \\
\text { GTGAGAGAGTACCTCGTTGAAATAG }\end{array}$ & 103 & $y=-0.249 x+11.9462$ & B. dothidea \\
\hline Cytospora spp. & CtBTFF1/CtBtFR1 & $\begin{array}{l}\text { GAGCGCATGAACGTCTACTT/ } \\
\text { GGAAGAAAGCGCGTCAGTAA }\end{array}$ & 106 & $y=-0.2873 x+13.22$ & $\mathrm{~N} / \mathrm{D}$ \\
\hline Diplodia spp. & $\mathrm{DpF} / \mathrm{DpR}$ & $\begin{array}{l}\text { GTGTAAGTTTGCGCTGTCTTTG/ } \\
\text { GTAGAGAGTACCTCGTTGAAGTAGA }\end{array}$ & 118 & $y=-0.2566 x+12.8618$ & D. mutila, D. seriata \\
\hline $\begin{array}{l}\text { Lasiodiplodia } \\
\text { spp. }\end{array}$ & LcBT-F2/LcBT-R2 & $\begin{array}{l}\text { CTGCTTTCTGGTTTGTTGCC/ } \\
\text { GAGAAGGCGCACACTTACA }\end{array}$ & 128 & $y=-0.3055 x+11.9171$ & L. citricola, L. parva \\
\hline $\begin{array}{l}\text { Neofusicoccum } \\
\text { spp. }\end{array}$ & NpBT-F2/NpBT-R2 & $\begin{array}{l}\text { ACCACAGGCAGACCATTTC/ } \\
\text { GTCGGAGGTGCCATTGTAG }\end{array}$ & 118 & $y=-0.2465 x+11.1531$ & $\begin{array}{l}\text { N. mediterraneum, } \\
\quad N . \text { parvum, N. vitifusiforme }\end{array}$ \\
\hline $\begin{array}{l}\text { Phomopsis/ } \\
\text { Diaporthe spp. }\end{array}$ & PhBT-F1/PhBT-R1 & $\begin{array}{l}\text { CATCGTTACTGACCTCGACTTT/ } \\
\text { ACGAGATTTGAAGACAGGGAATAG }\end{array}$ & 102 & $y=-0.2404 x+12.0255$ & $\mathrm{~N} / \mathrm{D}$ \\
\hline
\end{tabular}

${ }^{\mathrm{y}} y$ is $\log _{10}$ (DNA concentration in femtograms), and $x$ is the cycle threshold $(\mathrm{Ct})$ value from qPCR. All $R^{2}$ values are $>0.99$, and $P<0.001$.

${ }^{\mathrm{z}} \mathrm{N} / \mathrm{D}=$ species not defined. 
except for the orchards Dried plum-3 and Pistachio-3 (Fig. 1), demonstrating the high aggressiveness of this species as a canker-causing pathogen in most tree crops. There was a variation in incidence of Neofusicoccum spp. among different crops (Fig. 1), except that this pathogen was not detected in the Dried plum-3 orchard.

Comparison among the pathogen groups for each studied tree crop showed that incidences of Lasiodiplodia spp. were significantly higher than or equal to those of other pathogens for all the studied crops (Table 3), demonstrating the importance of this fungus as a canker-causing pathogen among the pathogen groups. Following this, $B$. dothidea and Cytospora spp. were ranked as second in importance in the dried plum and pistachio crops (Table 3 ). However, there was no difference in incidence among B. dothidea, Cytospora spp., Neofusicoccum spp., and Phomopsis spp. in almond (Table 3), and

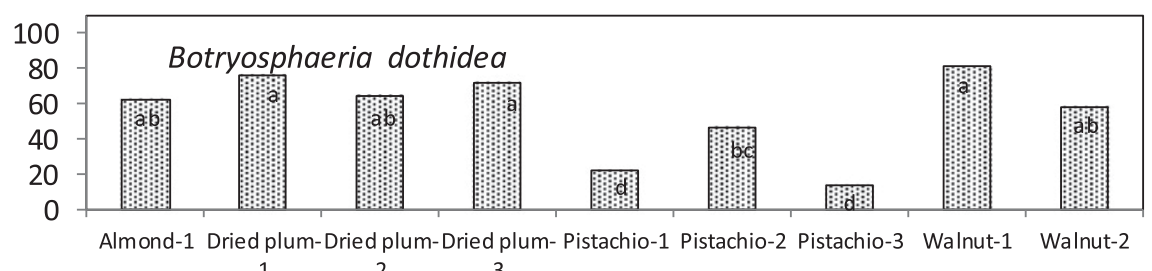

123

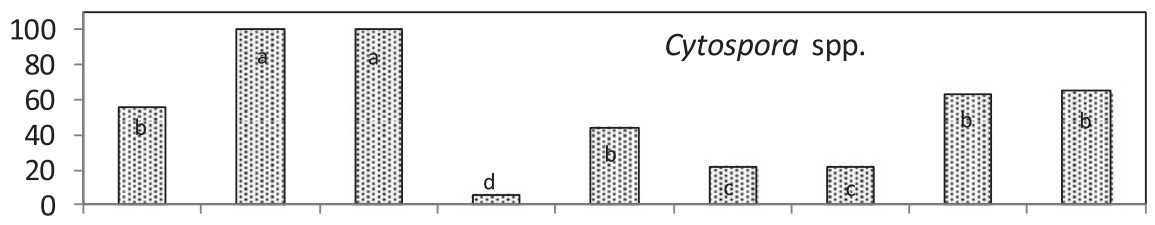

Almond-1 Dried plum-Dried plum-Dried plum- Pistachio-1 Pistachio-2 Pistachio-3 Walnut-1 Walnut-2 123
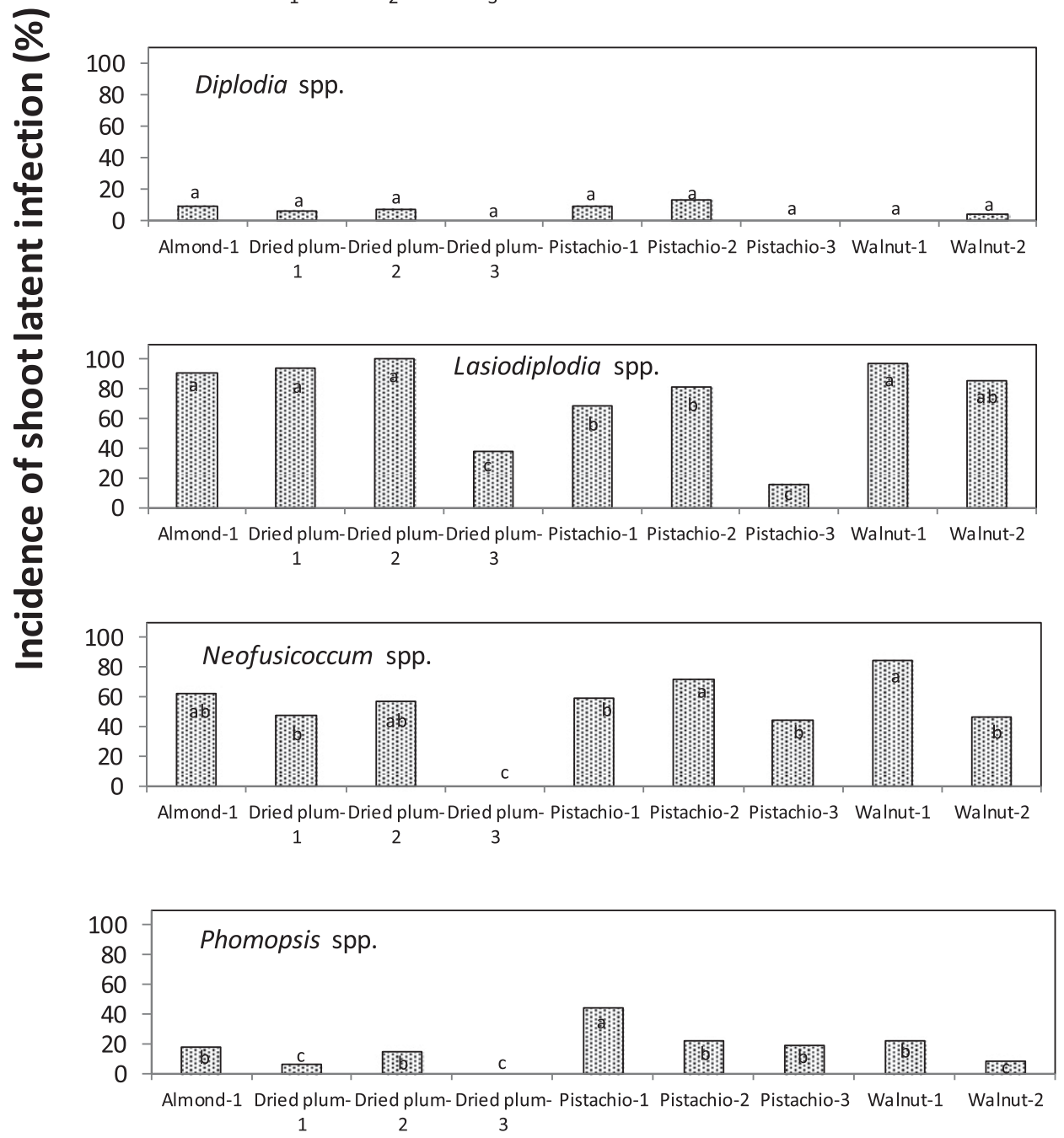

\section{Orchard of tree crop}

Fig. 1. Incidence (\%) of latent infection of shoots of different tree crops caused by six canker-causing pathogens determined in this study. Various numbers of samples were collected (Table 1). The previously published DNA primers and quantitative real-time PCR assays (Luo et al. 2017) were applied in this study to obtain the incidence data. The multiple comparisons in proportion data method (Zar 1999) was applied to determine the difference in incidence among orchards. The same letters in the bars indicate no significant difference in incidence for each canker-causing pathogen group at $P<0.05$. 
no difference in incidence among $B$. dothidea, Cytospora spp., and Neofusicoccum spp. was found (Table 3) in walnut.

MS of latent infection in shoots. Because the MS was calculated only from pathogen-positive samples, MS reflects the average severity level among the infected samples. The corresponding SD reflected the variation of MS among these positive samples. Generally, the MS values were in the range between 4.0 and 6.0 with SD from 0.0 to 1.0 for most cases (Fig. 2). The MS values of all studied pathogens in Dried plum-3 orchard were the lowest among all other orchards (Fig. 2). For B. dothidea, two walnut orchards and two dried plum orchards showed significantly higher MS than the other orchards (Fig. 2). Variation in MS of Cytospora spp. was detected among various orchards, whereas the highest MS was present in Dried plum-1 orchard, compared with the MS values in the other orchards (Fig. 2). The range of MS of Lasiodiplodia spp. was from 4.0 to 6.0 , with the lowest value in Dried plum-3 orchard (Fig. 2). There was no large difference in MS between Neofusicoccum spp. and Phomopsis spp. among the orchards (Fig. 2), demonstrating a similar situation in latent infection by these two pathogen groups.

Comparison in MS among different pathogen groups for each tree crop showed less variations. There was no significant difference in MS among six pathogen groups for dried plum and pistachio, except that Diplodia spp. showed lower MS than other pathogens for pistachio (Table 3). Similarly, MS of Lasiodiplodia spp. was significantly higher than that of Diplodia spp. on walnut, whereas no difference was found among other pathogen groups (Table 3). For almond, MS values of Lasiodiplodia spp. and Phomopsis spp. were significantly higher than those of other pathogen groups, whereas that of $B$. dothidea was also higher than those of Cytospora spp., Diplodia spp., and Neofusicoccum spp. (Table 3). The overall result demonstrated that no significant difference in MS among the six pathogen groups was found for most studied tree crops.

LII in shoots. Because LII combined the information of both incidence and severity, it can be used to reflect the general situation of latent infection and pathogen population level in an orchard. This study showed that the range of LII of both Diplodia spp. and Phomopsis spp. was below $10 \%$ in all the studied orchards, except for Phomopsis in the Pistachio-1 orchard (Fig. 3). The result implied less importance of these two pathogen groups in population development in the studied tree crops. However, the range of LII of B. dothidea was from 7 to $31 \%$, with lowest ones in two pistachio orchards (Pitachio-1 and Pistachio-2) (Fig. 3). Clearly, the highest LII occurred in two dried plum orchards at 53 and $41 \%$ for Dried plum-1 and Dried plum-2, respectively, which was much higher than the LII values of the other orchards (Fig. 3). The lowest LII of Lasiodiplodia spp. was determined in Dried plum-1 and Pistachio-3, whereas there was no significant difference in LII among other orchards, and the range of LII among these orchards was from 21 to 33\% (Fig. 3). These results demonstrated that this pathogen was well established across the studied tree crops. Basically, infection level of Neofusicoccum spp. was comparatively lower than the levels of the three pathogens mentioned above, and its LII values ranged across orchards from 14 to $34 \%$, with the highest one in Walnut-1 orchard (Fig. 3). Thus, this pathogen was also evenly distributed across the tree crops, but at a relatively low level. The overall range of LII values was below $50 \%$. In summary, there were major differences in the development of latent infection among these six canker-causing pathogen groups. Furthermore, variations in latent infection levels were detected also among the orchards used in this study.

Table 3. Comparisons in incidence, molecular severity (MS), and latent infection index (LII) of canker-causing pathogen groups for each of studied tree crops ${ }^{\mathrm{Z}}$

\begin{tabular}{|c|c|c|c|c|c|c|}
\hline \multirow[b]{2}{*}{ Tree crop } & \multicolumn{6}{|c|}{ Pathogen group } \\
\hline & $\begin{array}{l}\text { Botryosphaeria } \\
\text { dothidea }\end{array}$ & $\begin{array}{l}\text { Cytospora } \\
\text { spp. }\end{array}$ & $\begin{array}{l}\text { Diplodia } \\
\text { spp. }\end{array}$ & $\begin{array}{c}\text { Lasiodiplodia } \\
\text { spp. }\end{array}$ & $\begin{array}{l}\text { Neofusicoccum } \\
\text { spp. }\end{array}$ & $\begin{array}{c}\text { Phomopsis } \\
\text { spp. }\end{array}$ \\
\hline \multicolumn{7}{|c|}{ Incidence of latent infection } \\
\hline \multicolumn{7}{|l|}{ Shoots } \\
\hline Almond & $62.0 \mathrm{~b}$ & $56.0 \mathrm{~b}$ & $9.0 \mathrm{c}$ & $91.0 \mathrm{a}$ & $62.0 \mathrm{~b}$ & $17.6 \mathrm{bc}$ \\
\hline Dried plum & $70.9 \mathrm{a}$ & $68.7 \mathrm{ab}$ & $4.3 \mathrm{~cd}$ & $77.3 \mathrm{a}$ & $34.7 \mathrm{c}$ & $6.7 \mathrm{~d}$ \\
\hline Pistachio & $27.7 \mathrm{~b}$ & $29.3 \mathrm{~b}$ & $7.3 \mathrm{c}$ & $55.3 \mathrm{a}$ & $58.3 \mathrm{a}$ & $28.3 \mathrm{~b}$ \\
\hline Walnut & $69.5 \mathrm{~b}$ & $64.0 \mathrm{~b}$ & $2.0 \mathrm{~d}$ & $91.0 \mathrm{a}$ & $65.0 \mathrm{~b}$ & $15.0 \mathrm{c}$ \\
\hline \multicolumn{7}{|l|}{ Buds } \\
\hline Almond & $55.9 \mathrm{ab}$ & $47.1 \mathrm{~b}$ & $8.8 \mathrm{c}$ & $85.3 \mathrm{a}$ & $2.9 \mathrm{c}$ & $38.2 \mathrm{~b}$ \\
\hline Pistachio & $46.9 \mathrm{bc}$ & $50.0 \mathrm{~b}$ & $0.0 \mathrm{~d}$ & $50.0 \mathrm{~b}$ & $100.0 \mathrm{a}$ & $15.6 \mathrm{c}$ \\
\hline Walnut & $40.0 \mathrm{a}$ & $30.0 \mathrm{a}$ & $0.0 \mathrm{~b}$ & $0.0 \mathrm{~b}$ & $10.0 \mathrm{a}$ & $0.0 \mathrm{~b}$ \\
\hline \multicolumn{7}{|l|}{ MS } \\
\hline \multicolumn{7}{|l|}{ Shoots } \\
\hline Almond & $5.4 \pm 0.40 \mathrm{~b}$ & $5.07 \pm 0.39 \mathrm{c}$ & $6.40 \pm 0.41 \mathrm{a}$ & $4.60 \pm 0.44 \mathrm{~d}$ & $4.54 \pm 0.35 \mathrm{~d}$ & $5.8 \pm 0.59 \mathrm{a}$ \\
\hline Dried plum & $5.29 \pm 0.98 \mathrm{a}$ & $6.26 \pm 1.77 \mathrm{a}$ & $6.31 \pm 0.49 \mathrm{a}$ & $4.40 \pm 1.02 \mathrm{a}$ & $4.61 \pm 0.16 \mathrm{a}$ & $5.75 \pm 0.18 \mathrm{a}$ \\
\hline Pistachio & $4.98 \pm 0.21 \mathrm{ab}$ & $5.16 \pm 0.62 \mathrm{ab}$ & $5.37 \pm 0.11 \mathrm{ab}$ & $4.25 \pm 0.41 \mathrm{~b}$ & $5.70 \pm 0.62 \mathrm{a}$ & $5.63 \pm 0.85 \mathrm{a}$ \\
\hline Walnut & $5.98 \pm 0.12 \mathrm{ab}$ & $5.84 \pm 0.38 \mathrm{ab}$ & $6.76 \pm 0 \mathrm{a}$ & $5.45 \pm 0.46 \mathrm{~b}$ & $5.78 \pm 0.46 \mathrm{ab}$ & $6.02 \pm 0.49 \mathrm{ab}$ \\
\hline \multicolumn{7}{|l|}{ Buds } \\
\hline Almond & $5.20 \pm 0.38 \mathrm{~d}$ & $5.78 \pm 0.52 b c$ & $6.64 \pm 0.83 \mathrm{a}$ & $4.08 \pm 0.42 \mathrm{e}$ & $4.54 \pm 0$ cde & $6.21 \pm 1.23 \mathrm{ab}$ \\
\hline Pistachio & $4.74 \pm 0.74 b$ & $2.65 \pm 0.26 \mathrm{~d}$ & $\ldots$ & $4.2 \pm 0.42 \mathrm{c}$ & $5.39 \pm 0.68 \mathrm{a}$ & $5.63 \pm 0.63 \mathrm{a}$ \\
\hline Walnut & $4.5 \pm 0.31 \mathrm{a}$ & $4.24 \pm 0.13 \mathrm{ab}$ & $\ldots$ & $\ldots$ & $3.66 \pm 0 \mathrm{~b}$ & $\ldots$ \\
\hline \multicolumn{7}{|l|}{ LII } \\
\hline \multicolumn{7}{|l|}{ Shoots } \\
\hline Almond & $22.4 \mathrm{a}$ & $19.0 \mathrm{ab}$ & $3.8 \mathrm{c}$ & $27.9 \mathrm{a}$ & $18.8 \mathrm{ab}$ & $6.9 \mathrm{bc}$ \\
\hline Dried plum & $25.1 \mathrm{ab}$ & $32.4 \mathrm{a}$ & $1.5 \mathrm{c}$ & $24.1 \mathrm{ab}$ & $10.6 \mathrm{bc}$ & $2.6 \mathrm{c}$ \\
\hline Pistachio & $8.9 \mathrm{ab}$ & $10.1 \mathrm{ab}$ & $2.6 \mathrm{~b}$ & $15.6 \mathrm{a}$ & $21.9 \mathrm{a}$ & $10.6 \mathrm{ab}$ \\
\hline Walnut & $27.6 \mathrm{a}$ & $24.9 \mathrm{a}$ & $0.5 \mathrm{~b}$ & $32.9 \mathrm{a}$ & $25.4 \mathrm{a}$ & $6.3 \mathrm{~b}$ \\
\hline \multicolumn{7}{|l|}{ Buds } \\
\hline Almond & $19.4 \mathrm{a}$ & $18.1 \mathrm{a}$ & $3.9 \mathrm{~b}$ & $23.2 \mathrm{a}$ & $0.9 \mathrm{~b}$ & $15.8 \mathrm{a}$ \\
\hline Pistachio & $14.8 \mathrm{~b}$ & $8.8 \mathrm{~b}$ & $\ldots$ & $14.1 \mathrm{~b}$ & $35.9 \mathrm{a}$ & $6.0 \mathrm{~b}$ \\
\hline Walnut & $12.0 \mathrm{a}$ & $8.5 \mathrm{a}$ & $\ldots$ & $\ldots$ & $2.4 \mathrm{~b}$ & $\ldots$ \\
\hline
\end{tabular}

$\overline{\mathrm{z}}$ The multiple comparisons in proportion data method (Zar 1999) was applied to determine the differences in incidence and LII among pathogen groups for each tree crop. Comparison in MS among pathogen groups was performed with analysis of variance with LSD. Values followed by the same letters were not significantly different at $P<0.05$ among pathogen groups (in each row) for each tree crop in this study. 
Considering the comparisons in LII among pathogen groups in almond and dried plum, Diplodia spp. and Phomopsis spp. were significantly lower than those of the other four pathogen groups, in which no significant difference was found (Table 3). For pistachio, LIIs of Lasiodiplodia spp. and Neofusicoccum spp. were significantly higher than that of Diplodia spp., whereas they did not differ significantly from the LIIs of B. dothidea, Cytospora spp., and Phomopsis spp. (Table 3). Similarly, for walnut, LIIs of Diplodia spp. and Phomopsis spp. were significantly lower than those of the other four pathogen groups (Table 3 ).

Incidence of latent infection on buds. All the six pathogen groups were detected in buds collected from Almond-1 orchard.
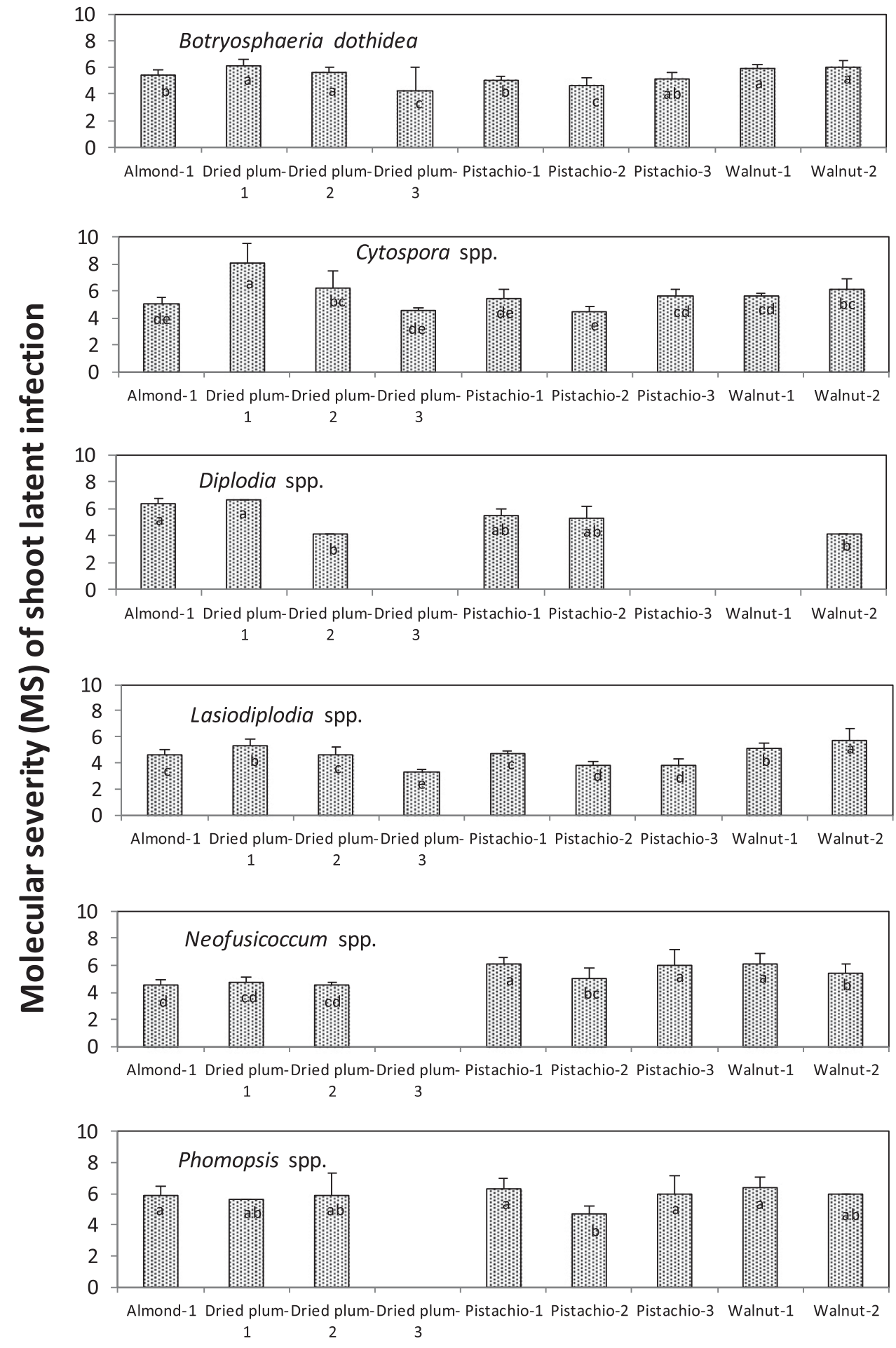

\section{Orchard of tree crop}

Fig. 2. Comparisons in mean molecular severity (MS, see the text for the definition) of latent infection of shoots from various tree crops for six canker-causing pathogen groups. The previously published DNA primers and quantitative real-time PCR assays (Luo et al. 2017) were applied in this study to determine the MS for each sample. Analysis of variance with LSD was applied to determine the difference in mean MS among orchards. Vertical bars represent the standard errors for the means. The same letters in the bars indicate no significant difference in MS for each canker-causing pathogen group at $P<0.05$. 
B. dothidea, Cytospora spp., Lasiodiplodia spp., Neofusicoccum spp., and Phomopsis spp. were detected in Pistachio-2 orchard, and only B. dothidea, Cytospora spp., and Neofusicoccum spp. were detected in Walnut-2 orchard (Fig. 4). No difference in the incidence of B. dothidea on buds among the three tree crops was found (Fig. 4). The incidences of Cytospora spp. in Almond-1 orchard and Pistachio-2 orchard were significantly higher than that in Walnut-2 orchard (Fig. 4), whereas those of Lasiodiplodia spp. and Phomopsis spp. in Almond-1 orchard were significantly higher than those in Pistachio-2 orchard (Fig. 4). Clearly, the incidence of Neofusicoccum spp. in Pistachio-2 orchard was much higher than those in Almond-1 and Walnut-2 orchards (Fig. 4).

Comparisons in incidence among the six pathogen groups for almond showed that $B$. dothidea and Lasiodiplodia spp. were
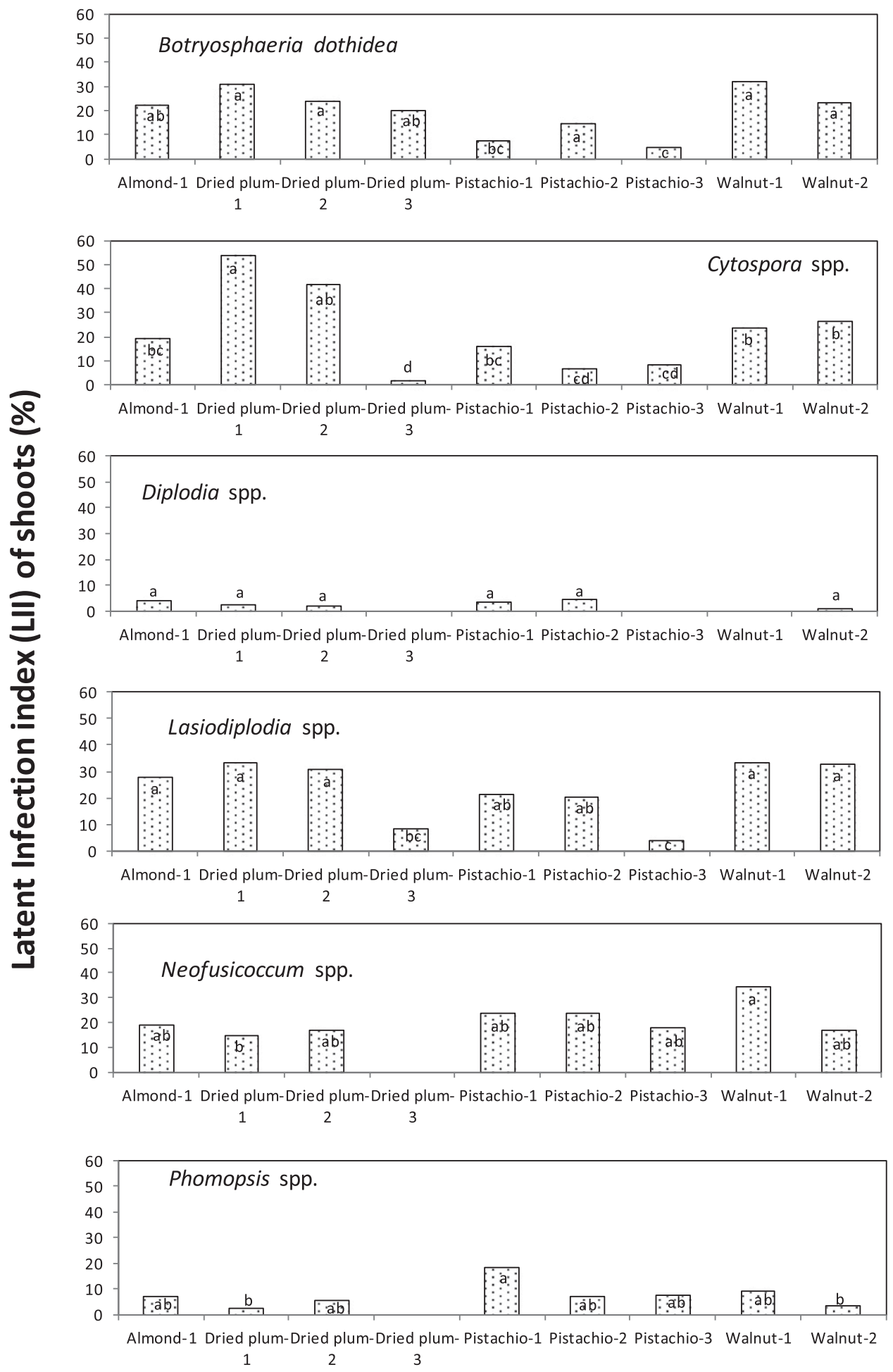

\section{Orchard of tree crop}

Fig. 3. Latent infection index (\%) of shoots (LII, see the text for definition and calculation) of canker disease quantified for the samples from different tree crops for six canker-causing pathogen groups. The multiple comparisons in proportion data method (Zar 1999) was applied to determine the difference in LII among orchards. The same letters in the bars indicate no significant difference in LII for each canker-causing pathogen group at $P<0.05$. 
significantly higher than those of the other four pathogen groups, whereas those of Diplodia spp. and Neofusicoccum spp. were the lowest (Table 3). However, Neofusicoccum spp. was detected on $100 \%$ buds of pistachio, whereas Diplodia spp. was not detected. The incidence of Phomopsis spp. was the lowest, and no differences in incidence among B. dothidea, Cytospora spp., and Lasiodiplodia spp. were detected (Table 3). However, Diplodia spp., Lasiodiplodia spp., and Phomopsis spp. were not detected in walnut buds, and no differences in the incidence among the other three pathogen groups were found (Table 3 ).

MS of latent infection on buds. The MS values of all the pathogen groups in Almond-1 orchards were significantly higher than or
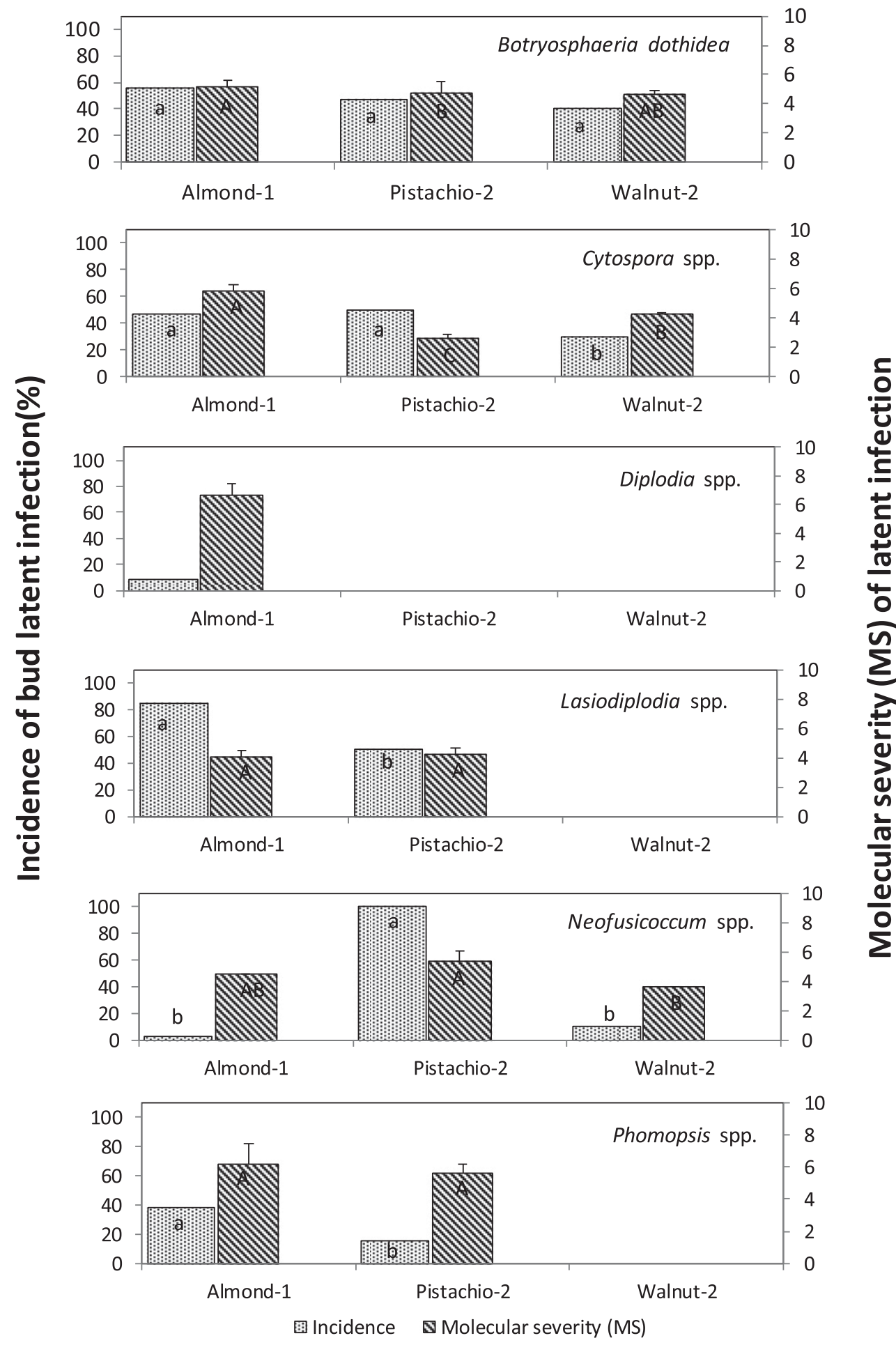

\section{Orchard of tree crop}

Fig. 4. Incidence (\%) and molecular severity (MS) of latent infections of six canker-causing pathogen groups for the bud samples collected from three tree-crop orchards. The multiple comparisons in proportion data method (Zar 1999) and analysis of variance with LSD were applied to determine the difference in incidence and mean MS among orchards, respectively. Vertical bars represent the standard errors for the means of MS. The same letters in lowercase and uppercase in the bars indicate no significant difference in incidence and mean MS, respectively, among orchards for each canker-causing pathogen group at $P<0.05$. 
equal to those of the other two orchards (Fig. 4). Differences in values of MS of Cytospora spp. among the three orchards were detected, and the MS of Neofusicoccum spp. in Walut-2 orchard was significantly lower than those in the other two orchards (Fig. 4). Comparisons showed large differences and great variation in MS values among the pathogen groups in almond and pistachio buds, whereas no significant difference in MS between $B$. dothidea and Cytospora spp. was detected in walnut buds (Table 3 ).

LII on buds. There was no significant difference in LII among the three crops for any of the six pathogen groups, except for the LII of Neofusicoccum spp. in Pistachio-2 orchard, which was significantly higher than those of the other two orchards (Fig. 5). Comparison among the different pathogen groups in almond buds showed that
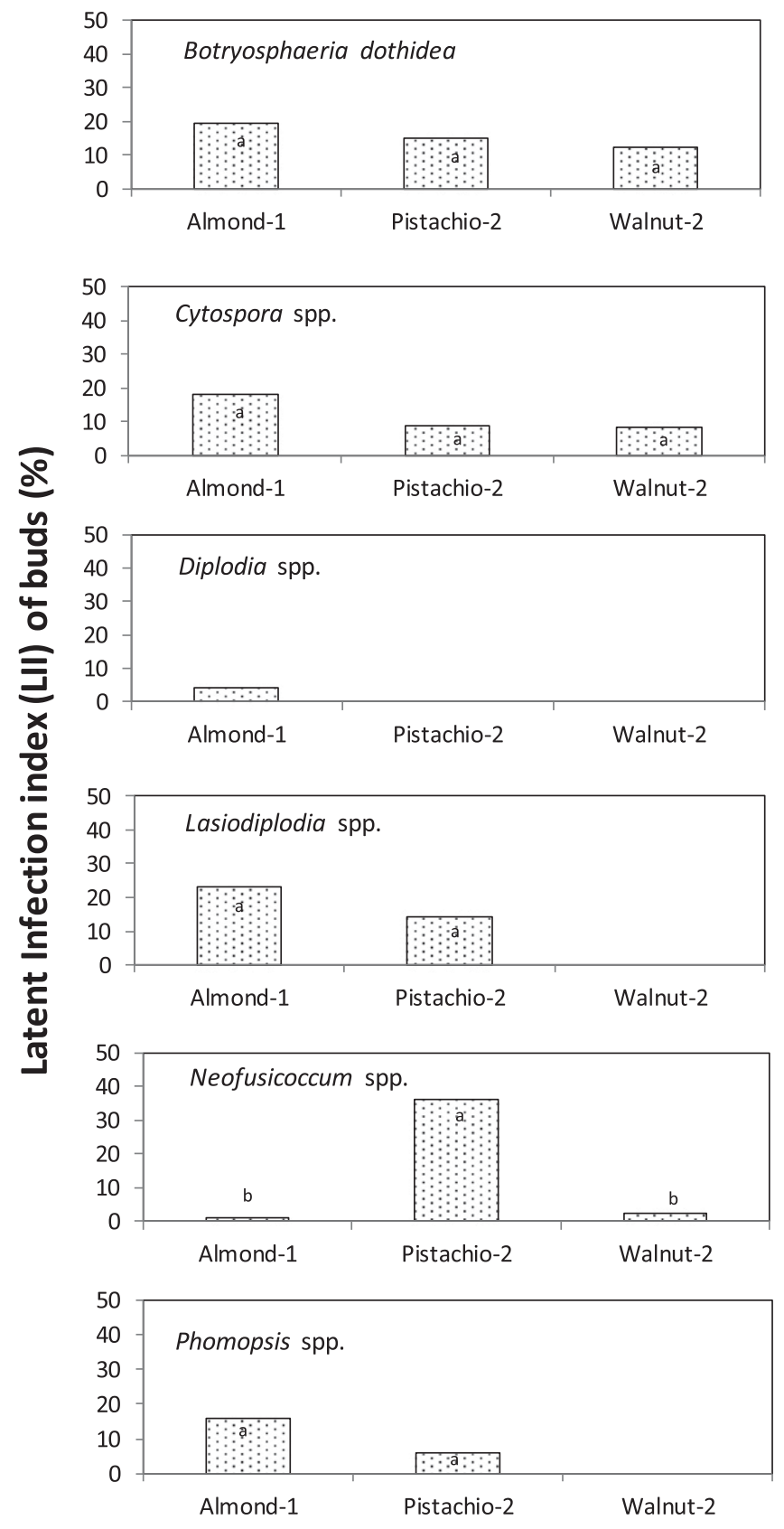

\section{Orchard of tree crop}

Fig. 5. Latent infection index (\%) (LII) of bud samples from three tree crops for six canker-causing pathogen groups used in this study. The multiple comparisons in proportion data method (Zar 1999) was applied to determine the difference in LII among orchards. The same letters in the bars indicate no significant difference in LII for each canker-causing pathogen group at $P<0.05$.
LIIs of B. dothidea, Cytospora spp., Lasiodiplodia spp., and Phomopsis spp. were significantly higher than those of other two pathogen groups (Table 3). In pistachio buds, LII of Neofusicoccum spp. was significantly higher than the LII of the other pathogen groups, whereas it was lower than those of B. dothidea and Cytospora spp. in walnut buds (Table 3).

Establishment of pathogen population in latent phase. Regarding the situation of pathogen latent population establishment that we arbitrarily defined in this study, Phomopsis spp. and Diplodia spp. were not found in some of the sampled orchards, or they were just found in the starting mode (Fig. 6). The latent populations of Lasiodiplodia spp. have been well established in several orchards of these four tree crops, and similar well-established situations were observed in a few orchards for B. dothidea and Neofusicoccum spp. populations. The latent infections of the pathogen populations were at the developing stage in most orchards (Fig. 6).

\section{Discussion}

Using the previously designed primers and qPCR assay, the results of this study help understand the current situation regarding latent phase of six canker-causing pathogen groups in shoots and buds of four different tree crops in California. Variations in the incidence of latent infection among canker-causing pathogen groups were observed, with Phomopsis spp. and Diplodia spp. showing low levels compared with those of the other four pathogen groups. High incidences caused by Cytospora spp. were observed in two dried plum orchards, and dried plum orchards in general are frequently affected by Cytospora canker. Most orchards showed high incidences caused by $B$. dothidea and Lasiodiplodia spp. and moderate levels caused by Neofusicoccum spp. Among the infected samples, the MSs were maintained at a certain range among pathogen groups and among tree crops. This may reflect the detectable infection level in the tissues before canker symptom appearance. The parameter LII reflected the overall latent situation of each pathogen in plant tissues, which can be used as a standard measurement in further studies to evaluate and compare situations among different causal pathogens and among various tree crops. Using the concept of latent pathogen population establishment, we classified each of the six pathogen population levels for the different sampled tree crops. This parameter quantified by diagnostic laboratories might be used to help growers estimate situations of latent infection levels in their orchards as a basic information for disease management and risk assessment of possible canker and pathogen population development.

We found that different canker-causing pathogens were predominant on different crops. For instance, the population of Cytospora spp. is in an increasing mode, and at present Cytospora is considered a major canker pathogen in dried plum orchards, whereas it is a minor pathogen in almond and walnut orchards. Phomopsis spp. could be detected relatively easier in walnut orchards than in dried plum orchards. Phomopsis spp. have been reported causing a canker and blight disease on walnut (Chen et al. 2014a) but only a fruit rot in wounded dried plum fruit (Michailides and Morgan 1993a). Neofusicoccum spp. now is becoming the major causal pathogen of band canker in almond orchards, whereas the population of this pathogen seemed not well established in dried plum and walnut orchards. However, Lasiodiplodia spp. was found in almost all orchards, indicating that it is the most aggressive pathogen of canker disease across the various tree crops, and the high latent infection levels reflected a high-risk potential of disease development in the future.

Symptoms and signs of canker diseases develop very slowly in shoots and other parts of trees, during which the pathogen development could last a long time without showing disease signs. Although the latent infection level of tissues by canker-causing pathogens could be very low, still the qPCR assay is better than the traditional plating isolation method, which could not detect any low infection. A previous study in our laboratory showed that the qPCR could passively detect samples with low infection levels for some specific pathogens, whereas the conventional method of culturing on agar media cannot detect them because of the low infection levels in the 
samples and the chance of contamination owing to long incubation time of plated tissues (data not shown). In other words, the whole process of canker-pathogen development inside the plant tissues is difficult to elucidate using traditional approaches. Our qPCR assay overcame this deficiency because it can detect and quantify low levels of latent infection. Thus, the method could be widely used to study the canker development and epidemiological mechanism before symptom appearance. Similar research had been performed by Luchi et al. (2005). They used species-specific primers in qPCR to detect and quantify Sphaeropsis sapinea from inoculated Pinus nigra shoots. Our study used a similar method to quantify not only one but six different canker-causing pathogens in naturally developed latent infections.

There are still many questions in the development and epidemiology of canker diseases. The initial infection process is still unclear. Regarding the possible epidemiological mechanisms of canker diseases, there might be several possibilities: First, canker development mainly relies on yearly infections through direct penetration, especially in severely infected orchards. With the exception of almond, inoculum originates mainly from diseased shoots, on which the canker fungi produce easily and abundantly the spore-producing structures, pycnidia and perithecia, during the season. Thus, spore inoculum splashed by rain and irrigation water (dried plum, almond, pistachio, and walnut) and airborne inoculum (almond and walnut) could serve as the main source of infection and disease development (Michailides 1991). Second, pruning wounds (and other type of wounds, e.g., those caused by hail, freezing, insects, birds, etc.) serve as entrance points for penetration and canker disease development. Specifically, pruning wounds could serve as sinks for infection from inoculum brought by rain or irrigation water splashing, air, insects, birds, or even spread from latent infections on the surface of a shoot (Slippers and Wingfield 2007). Finally, the groups of canker-causing pathogens behave as latent fungi and exist even early in young plants as they grow in a nursery. When these young plants are planted in the field, the latent fungi (Botryosphaeriaceae and Diaporthaceae) could accumulate as latent infection in the shoots of the growing trees (Y. Luo and T. J. Michailides, personal observations). Therefore, when trees encounter environmental stress (e.g., drought, freezing, nutrient deficiency, etc.) or even wounding (mechanical damage, pruning and hedging wounds), some of the latent species could transition to causing cankers. And because these pathogens could accumulate in shoots, canker disease epidemics might not necessarily rely on new yearly infections by external inoculum.

The latent fungi were broadly defined as those established inside healthy plant tissues without causing overt symptoms in or apparent injury to the host (Bills 1996; Petrini 1991). It is still under investigation to determine how the pathogens could exist in young plants, even in those from nurseries (Stanosz et al. 2005), and how they can develop after planting in the field. In our study, most shoot samples were 1 to 2 years old. The detected pathogens already existed in young plant tissues in a latent phase of the pathogen species. However, Bills (1996) identified a core group of organisms consisting of ascomycetous fungi. Along with applications of qPCR in plant pathological research, the pathogen establishment process could be detected and quantified at an early stage, and the mechanisms of interaction between host and pathogen could be more clearly defined. Understanding such processes may help monitor pathogen development and design proper disease management strategies.

How the latent pathogen could trigger the appearance of canker symptoms is a critical question, needing additional experimentation to obtain the answer. Because types of canker symptoms vary widely, depending on the tree crop, position of trees (bark of stems, branches, twigs, and even buds), period of growing season, and environments, the appearance of symptoms might not be always related to the accumulation of the pathogens around symptoms. Based on the common knowledge that the development of canker symptoms is linked to environmental stress, such stress might affect both host and latent pathogens. Using our sensitive qPCR approach, we might be able to determine the early process in interactions among host, pathogen, and environment. Moreover, it is still unknown whether such interaction could promote the development of some compounds inside plant tissues that are toxic to plant growth, leading to canker symptom appearance. Dynamics of latent pathogens during a growing season and even over years should be studied by using our qPCR system to figure out their development patterns, accumulation of latent infection, possible population change, and even adaption of the pathogens to environmental change. Extreme weather (heat or drought) in recent years in California might promote the quick development of canker disease in different tree crops. Therefore, different from row crops, multiyear research is needed to answer questions relevant to canker development and help design disease management strategies for different tree crops.

Chemical control and biocontrol of canker disease are still under study. In addition to uses of host resistance, prevention of entry of pathogenic species and genotypes into the orchards was recommended (Slippers and Wingfield 2007). Elimination of latent pathogens and reduction of their development in young plants, such as when they are produced in nurseries, might be suggested. Prediction of canker development trends based on monitoring latent pathogen development might help estimate the possible risk of future occurrence of canker disease depending on climatic situations. For all

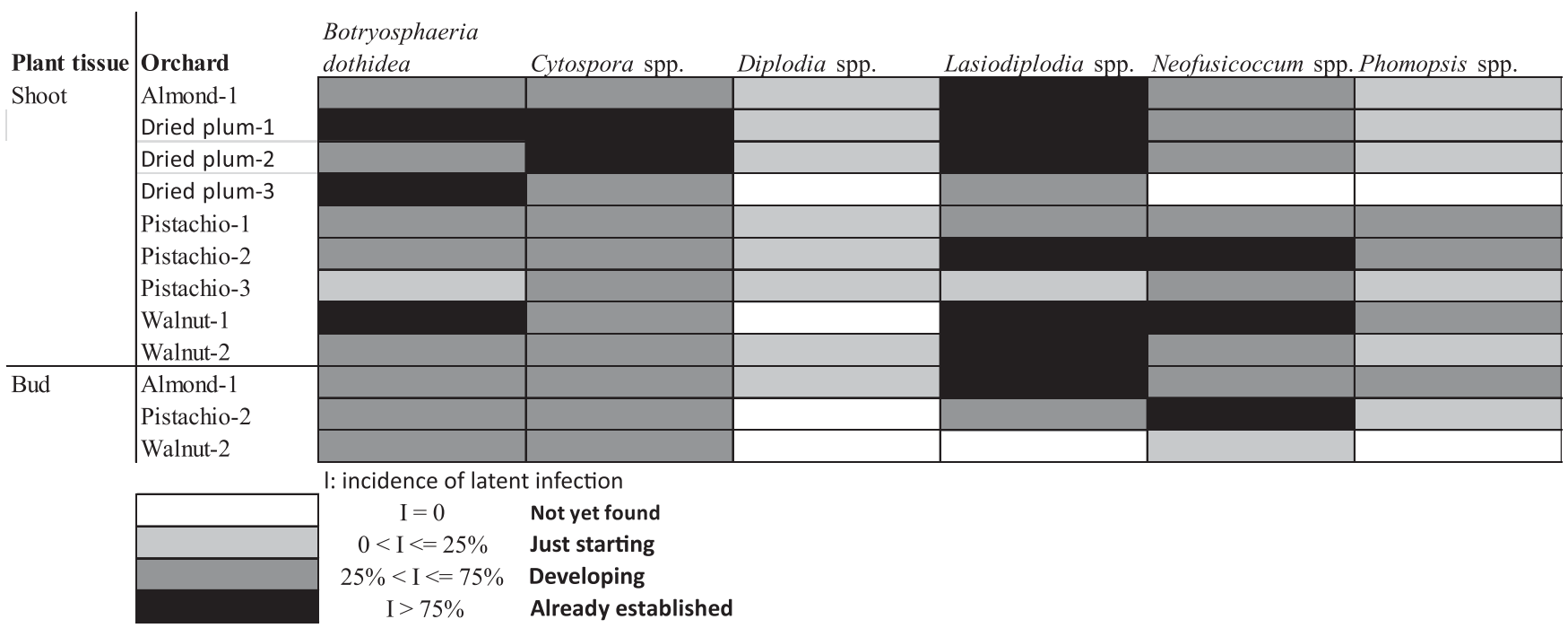

Fig. 6. Diagram chart of population establishment (see text for the definition) of six canker-causing pathogen groups in shoots and buds for various tree crop orchards used in this study. I = incidence. 
the above, our qPCR system could serve as efficient and valuable tool to achieve the proposed goals.

\section{Literature Cited}

Aćimović, S. G., Rooney-Latham, S., Albu, S., Grosman, D. M., and Doccola, J. J. 2018. Characterization and pathogenicity of Botryosphaeriaceae fungi associated with declining urban stands of coast redwood in California. Plant Dis. 102:1950-1957.

Adams, G. C., and Jacobi, W. R. 2016. Cytospora canker of hardwoods. Pages 91-93 in: Diseases of Trees in the Great Plains. General Technical Report RMRS-GTR-335. U.S. Department of Agriculture, Forest Service, Rocky Mountain Research Station, Fort Collins, CO.

Adesemoye, A. O., Mayorquin, J. S., Wang, D. H., Twizeyimana, M., Lynch, S. C., and Eskalen, A. 2014. Identification of species of Botryosphaeriaceae causing bot gummosis in citrus in California. Plant Dis. 98:55-61.

Ahimera, N., Gisler, S., Morgan, D. P., and Michailides, T. J. 2004. Effects of single-drop impactions and natural and simulated rains on the dispersal of Botryosphaeria dothidea conidia. Phytopathology 94:1189-1197.

Bills, G. F. 1996. Isolation and analysis of endophytic fungal communities from woody plants. Pages 31-63 in: Endophytic Fungi in Grasses and Woody Plants-Systematics, Ecology, and Evolution. S. C. Redlin and L. M. Carris, eds. APS Press, St. Paul, MN.

Brown, E. A., and Hendrix, F. F. 1981. Pathogenicity and histopathology of Botryosphaeria dothidea on apple stems. Phytopathology 71:375-379.

Chen, S. F., Morgan, D. P., Hasey, J. K., Anderson, K., and Michailides, T. J. 2014a. Phylogeny, morphology, distribution, and pathogenicity of Botryosphaeriaceae and Diaporthaceae from English walnut in California. Plant Dis. 98:636-652.

Chen, S. F., Morgan, D. P., and Michailides, T. J. 2014b. Botryosphaeriaceae and Diaporthaceae associated with panicle and shoot blight of pistachio in California, USA. Fungal Divers. 67:157-179.

Damm, U., Crous, P. W., and Fourie, P. H. 2007. Botryosphaeriaceae as potential pathogens of Prunus species in South Africa, with descriptions of Diplodia africana and Lasiodiplodia plurivora sp. nov. Mycologia 99:664-680.

Diogo, E. L. F., Santos, J. M., and Phillips, A. J. L. 2010. Phylogeny, morphology and pathogenicity of Diaporthe and Phomopsis species on almond in Portugal. Fungal Divers. 44:107-115.

English, H., Davis, J. R., and DeVay, J. E. 1975. Relationship of Botryosphaeria dothidea and Hendersonula toruloidea to a canker disease of almond. Phytopathology 65:114-122.

Gomes, R. R., Glienke, C., Videira, S. I. R., Lombard, L., Groenewald, J. Z., and Crous, P. W. 2013. Diaporthe: A genus of endophytic, saprobic and plant pathogenic fungi. Persoonia 31:1-41.

Inderbitzin, P., Bostock, R. M., Trouillas, F. P., and Michailides, T. J. 2010. A six locus phylogeny reveals high species diversity in Botryosphaeriaceae from California almond. Mycologia 102:1350-1368.

Kim, K. W., Park, E. W., and Ahn, K.-K. 1999. Pre-penetration behavior of Botryosphaeria dothidea on apple fruits. Plant Pathol. J. 15:223-227.

Luchi, N., Capretti, P., Surico, G., Orlando, C., Pazzagli, M., and Pinzani, P. 2005. A real-time quantitative PCR assay for the detection of Sphaeropsis sapinea from inoculated Pinus nigra shoots. J. Phytopathol. 153:37-42.

Luo, Y., Gu, S., Felts, D., Puckett, R. D., Morgan, D. P., and Michailides, T. J. 2017. Development of qPCR systems to quantify shoot infections by canker-causing pathogens in stone fruits and nut crops. J. Appl. Microbiol. 122:416-428.

Ma, Z., Boehm, E. W. A., Luo, Y., and Michailides, T. J. 2001a. Population structure of Botryosphaeria dothidea from pistachio and other hosts in California. Phytopathology 91:665-672.

Ma, Z., Luo, Y., and Michailides, T. J. 2001b. Resistance of Botryosphaeria dothidea from pistachio to iprodione. Plant Dis. 85:183-188.

Ma, Z., Luo, Y., and Michailides, T. J. 2004. Spatiotemporal changes in the population structure of Botryosphaeria dothidea from California pistachio orchards. Phytopathology 94:326-332.
McDonald, V., and Eskalen, A. 2011. Botryosphaeriaceae species associated with avocado branch cankers in California. Plant Dis. 95:1465-1473.

Michailides, T. J. 1991. Pathogenicity, distribution, sources of inoculum, and infection courts of Botryosphaeria dothidea on pistachio. Phytopathology 81: 566-573.

Michailides, T. J., and Morgan, D. P. 1993a. Wind scab of French prune: Symptomatology and predisposition to preharvest and postharvest fungal decay. Plant Dis. 77:90-95.

Michailides, T. J., and Morgan, D. P. 1993b. Spore release by Botryosphaeria dothidea in pistachio orchards and disease control by altering trajectory angle of sprinklers. Phytopathology 83:145-152.

Michailides, T. J., and Morgan, D. P. 2010. Diseases of tree nut crops caused by Botryosphaeriaceae fungi. CAPCA Adviser 13:34-35, 38-40.

Mila, A. L., Driever, G. F., Morgan, D. P., and Michailides, T. J. 2005. Effects of latent infection, temperature, precipitation, and irrigation on panicle and shoot blight of pistachio in California. Phytopathology 95:926-932.

Mila, A. L., and Michailides, T. J. 2006. Use of Bayesian methods to improve prediction of panicle and shoot blight severity of pistachio in California. Phytopathology 96:1142-1147.

Moral, J., Muñoz-Díez, C., González, N., Trapero, A., and Michailides, T. J. 2010. Characterization and pathogenicity of Botryosphaeriaceae species collected from olive and other hosts in Spain and California. Phytopathology 100: 1340-1351

Ntahimpera, N., Driever, G. F., Felts, D., Morgan, D. P., and Michailides, T. J. 2002. Dynamics and pattern of infection by Botryosphaeria dothidea on pistachio buds. Plant Dis. 86:282-287.

Pathak, T. B., Maskey, M. L., Dahlberg, J. A., Kearns, F., Bali, K. M., and Zaccaria, D. 2018. Climate change trends and impacts on California agriculture: A detailed review. Agronomy (Basel) 8:25

Petrini, O. 1991. Fungal endophytes of tree leaves. Pages 179-197 in: Microbial Ecology of Leaves. J. H. Andrews and S. S. Hirano, eds. Springer, New York, NY.

Phillips, A. J. L., Alves, A., Abdollahzadeh, J., Slippers, B., Wingfield, M. J. Groenewald, J. Z., and Crous, P. W. 2013. The Botryosphaeriaceae: Genera and species known from culture. Stud. Mycol. 76:51-167.

Rossman, A. Y., Farr, D. F., and Castlebury, L. A. 2007. A review of the phylogeny and biology of the Diaporthales. Mycoscience 48:135-144.

Senanayake, I. C., Crous, P. W., Groenewald, J. Z., Maharachchikumbura, S. S. N., Jeewon, R., Phillips, A. J. L., Bhat, J. D., Perera, R. H., Li, Q. R., Li, W. J., Tangthirasunun, N., Norphanphoun, C., Karunarathna, S. C., Camporesi, E., Manawasighe, I. S., Al-Sadi, A. M., and Hyde, K. D. 2017. Families of Diaporthales based on morphological and phylogenetic evidence. Stud. Mycol. 86:217-296.

Slippers, B., and Wingfield, M. J. 2007. Botryosphaeriaceae as endophytes and latent pathogens of woody plants: Diversity, ecology and impact. Fungal Biol. Rev. 21:90-106.

Stanosz, G. R., Smith, D. R., and Albers, A. J. 2005. Surveys for asymptomatic persistence of Sphaeropsis sapinea on or in stems of red pine seedlings from seven Great Lakes region nurseries. For. Pathol. 35:233-244.

Udayanga, D., Liu, X. Z., McKenzie, E. H. C., Chukeatirote, E., Bahkali, A. H. A. and Hyde, K. D. 2011. The genus Phomopsis: Biology, applications, species concepts and names of common phytopathogens. Fungal Divers. 50:189-225.

Úrbez-Torres, J. R., and Gubler, W. D. 2009. Pathogenicity of Botryosphaeriaceae species isolated from grapevine cankers in California. Plant Dis. 93:584-592.

Úrbez-Torres, J. R., Leavitt, G. M., Voegel, T. M., and Gubler, W. D. 2006 Identification and distribution of Botryosphaeria species associated with grapevines cankers in California. Plant Dis. 90:1490-1503.

Úrbez-Torres, J. R., Peduto, F., Vossen, P. M., Krueger, W. H., and Gubler, W. D. 2013. Olive twig and branch dieback: Etiology, incidence, and distribution in California. Plant Dis. 97:231-244.

Zar, J. H. 1999. Biostatistical Analysis, 4th Ed. Prentice-Hall, Englewood Cliffs, NJ. 